\title{
Nutritional Pattern of the Diet on the Eve of Decontrol
}

\author{
By Dorothy F. Hollingsworth, Scientific Adviser's Division, Ministry of Food, \\ Great Westminster House, Horseferry Road, London, S.W.I

\section{Comparison with American and British prewar diets}

It is more practical to think of the pattern of a diet in terms of food than of nutrients. For the purposes of the present paper the nutritional pattern of the diet has, therefore, been based on the familiar advice given by Sherman in his text books (cf. Sherman \& Lanford, I943; Sherman, 1946), and attributed by him to Gillett* in the early thirties, on the allocation of food expenditure between five groups of foods. The groups chosen for their nutritional properties were vegetables and fruit; milk and cheese; meats, fish and eggs; bread and cereals; and fats, sugar, other groceries and other food adjuncts. Gillett recommended that roughly one-fifth of total food expenditure of American city families should be allocated to each of these groups, the aim being to devise a diet more economical than the American average. The proportions must depend at any time and place on relative prices and the existence of such special schemes as cheap and free milk for mothers, infants and schoolchildren. Thus, these prewar American recommendations do not necessarily have any relevance to either prewar or postwar British practice. It is, however, instructive to compare British expenditure patterns with Gillett's recommendations.

The patterns of food expenditure on the five food groups in 1936-7 (Crawford \& Broadley, 1938) and in 1952 (Ministry of Food: National Food Survey Committee, 1954) are compared in Table $\mathrm{I}$.

\section{Table 1. Patterns of domestic expenditure on food 1936-7 and 1952}

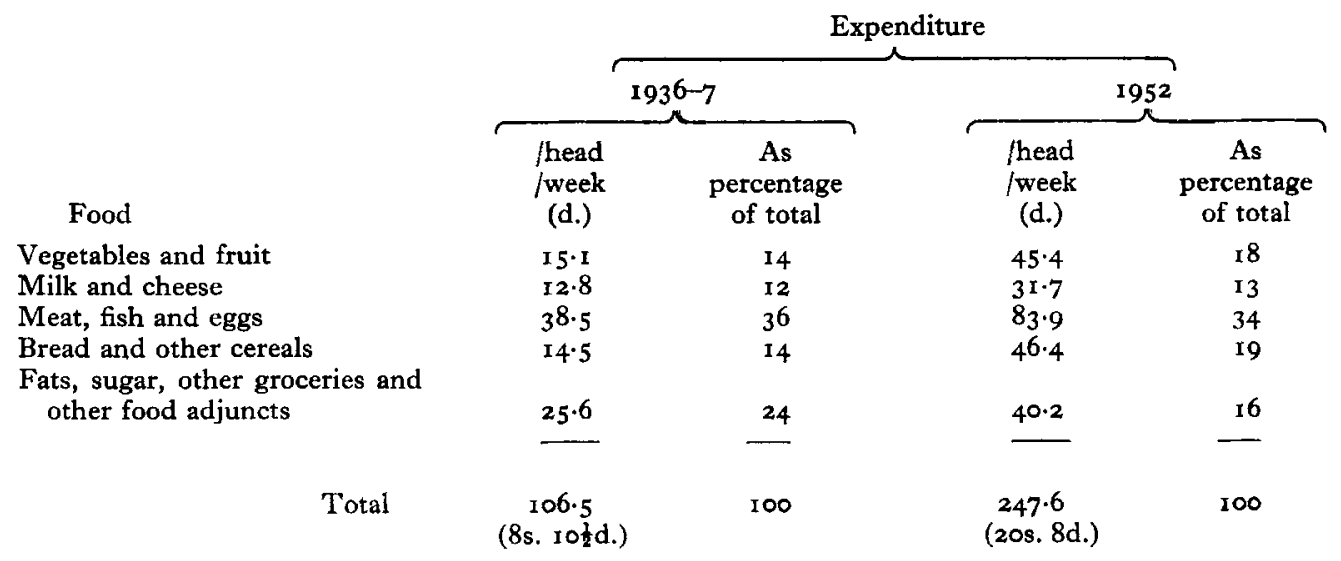

\footnotetext{
* At that time Director of the Nutrition Bureau of the Association for Improving the Conditions of the Poor in New York City, and subsequently Director of the Nutrition Service of the Community Service Society of the same city.
} 
Two points must be made about the comparison. The first, that the $193^{6-7}$ proportion of expenditure on vegetables and fruit is low compared with that in $195^{2}$ partly on account of the seasonal nature of the earlier records. The second, that in I952 the actual consumption of liquid milk was relatively higher than expenditure when welfare and school milk were taken into account.

The prewar pattern of British food expenditure was unlike the American recommendation with its greater emphasis on meat, fish and eggs and fats, sugar, at the expense of the so-called 'protective foods'-fruits and vegetables, and milk and cheese. The I 952 pattern was, on the other hand, more nearly similar as regards expenditure on vegetables and fruit and on bread and cereals. The proportion spent on milk and cheese was smaller than that recommended, but this must be interpreted in the light of the policy of fortifying flour with calcium carbonate as well as of the milk schemes. The most marked diversion from the American 'fifths' was the proportion spent on meats, fish and eggs which, at about a third of the total, was only slightly less than the prewar proportion. The British $195^{2}$ pattern divides approximately into thirds, i.e. one-third on vegetables, fruit, milk and cheese (the 'protective' group of McCollum); one-third on meats, fish and eggs; and one-third on bread and cereals, fats, sugar and other groceries (the foods providing most of the energy in the diet).

\section{The $195^{2}$ pattern}

Two further points should be made about the $195^{2}$ pattern. The first is that, in comparison with nutritional allowances recommended by the British Medical Association: Committee on Nutrition (1950), the average diet was adequate in all respects. The second is that the pattern represented an allocation of expenditure still restrained by rationing which had been in force for $\mathrm{I} 3$ years: thus, no permanent

Table 2. Pattern of domestic expenditure by class, 1952

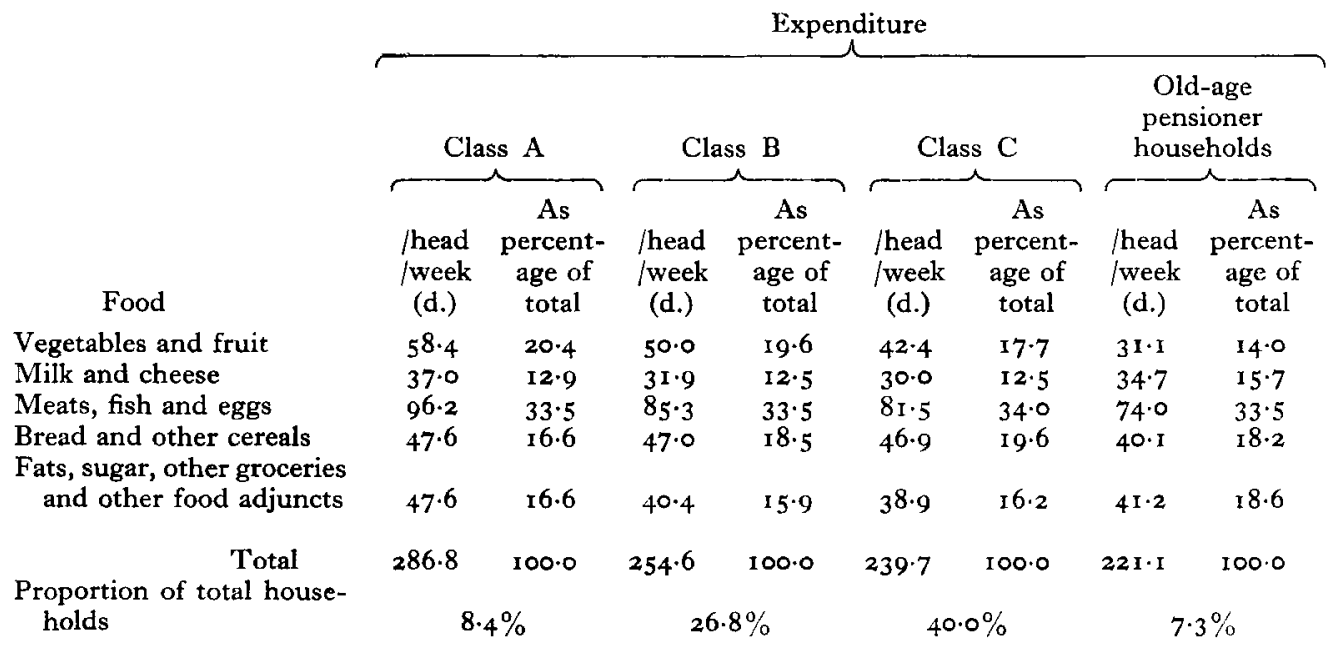

Class $A$, income of head of household $£ 650$ and over; class $B, £ 400-£ 649$; class $C, £ 225-£ 399$. 
conclusions about the pattern of expenditure under conditions of freedom are yet possible.

National Food Survey records have shown a remarkable nutritional uniformity in different social classes, industrial or occupational groups and geographical regions. As an illustration of the uniformity of pattern in different classes Table 2 gives the division of the 1952 data for certain classes determined according to the income of the head of the household (see Ministry of Food: National Food Survey Committee, 1954). All groups spent about one-third of their food budget on meats, fish and eggs. The patterns for classes $A$ and $B$ fitted the 'thirds' almost exactly, and class $\mathrm{C}$ and the old-age pensioner households spent about $30 \%$ on vegetables, fruit, milk and cheese, and $36-37 \%$ on the 'energy' group. Old-age pensioner households did, however, spend relatively more on milk and cheese than on vegetables and fruit.

The pattern of the diet may also be examined in relation to the contributions of these food groups to the nutrient totals. Table 3 shows their contributions to energy value, protein, calcium and iron totals for all households for 1952 (Ministry of Food: National Food Survey Committee, I954).

Table 3. Daily contributions of five groups of food to total energy value, protein, calcium and iron for all households, 1952

\begin{tabular}{|c|c|c|c|c|c|c|c|c|}
\hline Food group & Ener & $\begin{array}{l}\text { value } \\
\text { As } \\
\text { percent- } \\
\text { age of } \\
\text { total }\end{array}$ & $\mathrm{g}$ & $\begin{array}{l}\text { As } \\
\text { percent- } \\
\text { age of } \\
\text { total }\end{array}$ & $\mathrm{mg}$ & $\begin{array}{l}\text { As } \\
\text { percent- } \\
\text { age of } \\
\text { total }\end{array}$ & $\mathrm{mg}$ & $\begin{array}{l}\text { ron } \\
\text { As } \\
\text { percent- } \\
\text { age of } \\
\text { total }\end{array}$ \\
\hline Vegetables and fruit & 258 & II & 7 & 9 & 84 & 8 & $2 \cdot 9$ & 22 \\
\hline Milk and cheese & 301 & 12 & I6 & 2 I & 563 & 54 & 0.5 & 4 \\
\hline Meat, fish and eggs & 357 & I4 & $2 \mathrm{I}$ & 27 & 23 & 2 & $3 \cdot 7$ & 29 \\
\hline Bread and other cereals & 970 & 40 & 30 & 39 & $33 \mathrm{I}$ & 32 & $5 \cdot I$ & 39 \\
\hline $\begin{array}{l}\text { Fat, sugar, other groceries } \\
\text { and other food adjuncts }\end{array}$ & 561 & 23 & 3 & 4 & 42 & 4 & 0.8 & 6 \\
\hline Total & 2447 & 100 & 77 & 100 & 1043 & 100 & I $3 \cdot 0$ & 100 \\
\hline
\end{tabular}

It will be seen that the proportions shown for nutrients were very different from those for expenditure. Protein and iron were nearest to the expenditure pattern, though for each the 'energy' group provided over $40 \%$ of the total. Indeed, bread and cereals alone supplied roughly $40 \%$ of the total energy, protein and iron, and cost just under $20 \%$ of the total. The energy and calcium patterns were far from the 'thirds'. Two-thirds of the energy value was derived from the 'energy' group which cost just over one-third of the total, and nearly two-thirds of the calcium came from the 'protective' group which cost just under one-third of the total.

\section{Nutrient range between classes}

The wide differences in nutrient intake shown in the diets of the various income groups before the war as revealed by the surveys of Orr (1936) and Crawford \& 
Broadley (1938) are well known. Data are not available on which to recalculate the prewar nutrient figures into terms comparable with present results. Thus, we are only able to compare class differences by studying the ranges between classes. When the nutrient range between the lowest and highest income groups expressed as a percentage of the average for all groups is compared, for prewar and recent years, a considerable decrease in class gradient is evident. This is shown strikingly in Table 4, which gives the class ranges for the different nutrients for $1936-7$ and for the equivalent period of $195^{\circ}$. The reductions are marked for all nutrients, and particularly so for thiamine and calcium, features which are largely associated with the

Table 4. Comparison of nutrient range between lowest and highest income groups, expressed as a percentage of the average for all groups, in $193^{6-7}$ and $195^{\circ}$

$\begin{array}{lcc} & \text { October } 1936-\text { March } 1937 & \text { Ist and } 4 \text { th quarters } 1950 \\ \text { Energy value } & 40 & 11 \\ \text { Protein } & 44 & 13 \\ \text { Calcium } & 88 & 20 \\ \text { Iron } & 47 & 18 \\ \text { Vitamin A } & 81 & 34 \\ \text { Thiamine } & 71 & 9 \\ \text { Vitamin C } & 113 & 42\end{array}$

improved nutrient content of postwar bread and flour and, for calcium, with the increased consumption of milk.

\section{Consideration of different foods}

In turning to a more detailed consideration of individual foods, four groups have been selected in which there were no rationing restraints at the time of the $195^{2}$ survey. These are milk, bread and flour, vegetables and fruits, and fish.

Milk was freely available after January 1950; the composition, but not the consumption, of bread and flour was controlled; supplies of vegetables have not been controlled since potatoes were freed from rationing in April 1948; since the cessation of the distribution scheme for oranges in May $195^{\circ}$ and of the restriction on banana sales in April I95I, fruit has been plentifully available; supplies of fish have never been directly controlled to consumers. Thus, the consumption data presented may give some indication of the preference of the type of families studied for these particular foods.

Milk. Trends in milk consumption up to 1950 have already been reported to this Society (Hollingsworth, 195 I): whereas the average consumption of liquid milk had by 1949 increased by about $50 \%$ compared with prewar, that of class $\mathrm{C}$, the main group of the working class, had nearly doubled and that of class $\mathrm{D}$ had trebled. Since 1949 class improvements of this order have been maintained. In 1952, class A actually consumed 6.2 pt. of liquid and processed milk per head per week compared with $5.3 \mathrm{pt}$. in class $\mathrm{B}, 4.9 \mathrm{pt}$. in class $\mathrm{C}, 4.7 \mathrm{pt}$. in class D and $5^{.1} \mathrm{pt}$. for all households (Ministry of Food: National Food Survey Committee, 1954). The equivalent figures for prewar were $5.2,4.5,2.9,2 \cdot 1$ and $3.2 \mathrm{pt}$. 
If milk consumption is examined according to size rather than class of household it is found that milk consumption per head decreases with increasing numbers of children and adolescents. For any year from $195^{\circ}$ onwards, when a national sample was introduced, milk consumption by these types of household has followed a similar pattern. In $195^{2}$, for instance, households containing no child or one child under $\mathrm{I}_{4}$ consumed about $5.8 \mathrm{pt}$./head/week; those with two children $5.4 \mathrm{pt}$; those with three children $5^{\cdot}$ I pt.; those with four or more children $4.7 \mathrm{pt}$.; and those with children and adolescents (aged 14-20 inclusive) 4.5 pt. (Ministry of Food: National Food Survey Committee, 1954). Variations in milk consumption are one of the keys to the differences found in the nutritional composition of the diet in households containing different numbers of young dependents (Brown, I955; Gibson, Readman \& Warnock, 1955). The larger households are those whose diets tend to be short of protein and calcium, and to be border-line in respect of riboflavin. Fresh and processed milks supplied over $50 \%$ of calcium, over $40 \%$ of riboflavin and about $20 \%$ of protein in the diets of households with various numbers of children, compared with $44 \%, 37 \%$, and $16 \%$ respectively in those of households with children and adolescents. An increase in milk consumption in these latter households seems particularly desirable.

School milk is included in all estimates given. There is no evidence that uptake varies with class, but it appears to fall off as the age of the child increases. In 1952, for children aged $5^{-1} 3$ the average number of milk issues taken per child at school per day was 0.82 ; for children aged $14,0.63$; and for children aged 15 and over, 0.54 (Ministry of Food: National Food Survey Committee, 1954). This confirms the need for encouraging the older children, as well as adolescents, to drink more milk.

Bread and flour. When flour was controlled at $80 \%$ extraction, bread and flour provided in the average diet $30 \%$ of energy value, $32 \%$ of protein, $28 \%$ of calcium and iron, $35 \%$ of thiamine and $29 \%$ of nicotinic acid. Owing to the differences in consumption in the various classes and family groups, bread and flour are not of the same nutritional importance for all types of household. They are more important for class $\mathrm{C}$ and the old-age pensioner households than for class $\mathrm{A}$, providing between 30 and $40 \%$ of the nutrients mentioned in the two former classes compared with between 20 and $30 \%$ in class $\mathrm{A}$. They are also important in the diets of the larger families particularly those containing adolescents. The highest contributions, $33 \%$ of total energy value, $37 \%$ of protein, $32 \%$ of calcium, $30 \%$ of iron, $38 \%$ of thiamine, and $32 \%$ of nicotinic acid occurred in households with adolescents and children (Ministry of Food: National Food Survey Committee, 1954).

Fruits and vegetables. The distribution of vitamin C, unlike that of the nutrients provided by bread and milk, shows marked class and family-type differences (Table 5). In particular class $A$ and, to a lesser extent, the childless households and those with one child appear to differ from the remainder in that they obtain absolutely more total vitamin $\mathrm{C}$ than other groups and relatively more from fruit and tomatoes, (Ministry of Food: National Food Survey Committee, 1954). In comparison the 
Table 5. Proportion of vitamin $C$, expressed as a percentage of the total intake, obtained from potatoes, fruit and tomatoes, and green vegetables by different types of household in 1952

Household
Class A
Class B
Class C
Old-age pensioner

$\begin{array}{cccc}\text { Total }{ }^{*} / \text { head/day } & \begin{array}{c}\text { Obtained } \\ \text { from } \\ \text { potatoes } \\ (\mathrm{mg})\end{array} & \begin{array}{c}\text { Obtained from } \\ \text { fruit and } \\ \text { tomatoes } \\ (\%)\end{array} & \begin{array}{c}\text { Obtained from } \\ \text { green } \\ \text { vegetables } \\ (\%)\end{array} \\ 64 & 23 & 47 & 12 \\ 56 & 36 & 36 & 12 \\ 51 & 39 & 29 & 14 \\ 44 & 36 & 27 & 16\end{array}$

Containing one male and one female adult and:

No other

One child

Three children

Four or more children

Adolescents only

Children and adolescents

All households

64
$\mathbf{5 9}$
44
43
60
49

53

33
36
39
44
35
41

*With allowances for cooking losses.

remaining classes and groups obtain a higher proportion of their vitamin $\mathrm{C}$ from potatoes.

This point is even more strikingly made when the expenditure on these foods per family is considered: whereas the addition of each child to the household was accompanied by an increase in household expenditure on potatoes, no such increase occurred for green vegetables and none for fruits and tomatoes after the second child (Ministry of Food: National Food Survey Committee, 1954).

Fish. Fish takes a small, and apparently decreasing, place in domestic food consumption, a feature which is disturbing from the nutritional aspect, in view of the potential value of fish as a cheap source of valuable nutrients, especially of protein. Thus in $195^{2}$, the fish purchased provided $30 \%$ more protein per penny than meat, and rather more compared with eggs. Further, sea fish is a potential source of iodine* and fatty fish is one of the few rich sources of vitamin D: in $195^{2}$ it provided $27 \%$ of the vitamin $\mathrm{D}$ for all households (if that from cod-liver oil and vitamin $\mathrm{A}$ and D tablets is excluded) (Ministry of Food: National Food Survey Committee, 1954), with proportions varying from $37 \%$ in adult households to $17 \%$ in those containing four or more children.

Consumption of fish by families of different size has been studied over 3 years (Ministry of Food, r953), and it has been found that the demand for fresh and processed fish falls off steeply with the addition of each child, whereas that for cooked, canned and manufactured fish increases. Indeed, it seems that fresh and processed white and fat fish tend to be bought specifically for consumption by adults and adolescents. Table 6 shows that, on average over the 3 years, the total household purchases of fish remained constant, or (in $195^{\circ}$ and $195^{1}$ ) actually fell, as the

* A net consumption of 8-9 oz./head/week has been recommended as a source of iodine (Ministry of Health: Advisory Committee on Nutrition, 1937) 
Table 6. Purchases of fish by different types of household in 1950, 1951 and $195^{2}$ (g/household/week)

\begin{tabular}{|c|c|c|c|}
\hline Household & I $95^{\circ}$ & I95 I & I 952 \\
\hline $\begin{array}{l}\text { Containing one male and one } \\
\text { female adult and: }\end{array}$ & & & \\
\hline No other & $2 I \cdot I$ & 24.0 & $23: 3$ \\
\hline One child & 19.8 & $2 \mathrm{I} \cdot 8$ & $21 \cdot 0$ \\
\hline Two children & $20 \cdot 5$ & $23 \cdot 6$ & $21 \cdot 8$ \\
\hline Three children & $19 \cdot 4$ & $25 \cdot 6$ & 23.7 \\
\hline Four or more children & $18 \cdot 7$ & 20.9 & $27 \cdot 5$ \\
\hline Adolescents only & 28.9 & $3 I \cdot 3$ & $29 \cdot 7$ \\
\hline Children and adolescents & $30 \cdot 0$ & $32 \cdot 3$ & $3^{x} \cdot 7$ \\
\hline
\end{tabular}

number of children increased, indicating that even if the children were assumed to eat no fish the consumption per adult would itself be reduced in the larger families. It seems valid to conclude from such figures that children not only do not eat much fish but that their presence in the family actually tends to discourage adult members from doing so. This is incidentally not a class difference, since childless households are not, in general, of higher income status than those with children. The records suggest that fish was replaced by eggs rather than by meat in such households under the supply conditions then prevailing.

\section{REFERENCES}

British Medical Association: Committee on Nutrition (1950). Report of the Committee on Nutrition. London: British Medical Association.

Brown, J. A. C. (1955). Proc. Nutr. Soc. 14, 63.

Crawford, W. \& Broadley, H. (1938). The People's Food. London: William Heinemann Ltd.

Gibson, E. H., Readman, W. L. \& Warnock; G. M. (1955). Proc. Nutr. Soc. 14, 80.

Hollingsworth, D. F. (I95I). Brit. F. Nutr. 5, 392.

Ministry of Food (r953). Bull. Minist. Fd, Lond., no. 723, p. 8.

Ministry of Food: National Food Survey Committee (1952). Domestic Food Consumption and Expenditure, 1950. London: H.M. Stationery Office.

Ministry of Food: National Food Survey Committee (1954). Domestic Food Consumption and Expenditure, 1952. London: H.M. Stationery Office.

Ministry of Health: Advisory Committee on Nutrition (1937). First Report. London: H.M. Stationery Office.

Orr, J. B. (1936). Food, Health and Income. London: Macmillan and Co. Ltd.

Sherman, H. C. (1946). Chemistry of Food and Nutrition, 7 th ed. New York: The Macmillan Company. Sherman, H. C. \& Lanford, C. S. (I943). Essentials of Nutrition, 2nd ed. New York: The Macmillan Company.

\section{The Diets of Elderly Women Living Alone}

By A. H. J. Barnes, Statistics and Intelligence Division, Ministry of Food, 12-14 Sussex Place, London, N.W.I and Dorothy F. Hollingsworth, Scientific Adviser's Division, Ministry of Food, Great Westminster House, Horseferry Road, London, W. I

National Food Survey records reflect the food habits of complete families, but those supplied by informants living alone provide data from which it is possible to assess the food consumption of the individuals concerned. The opportunity was 